\title{
Biopsychosocial Factors Associated with Postpartum Haemorrhage in Surakarta, Central Java
}

\author{
Rizqa Kartika Dewi'), Uki Retno Budihastuti²), Eti Poncorini Pamungkasari3) \\ 1)Masters Program in Public Health, Universitas Sebelas Maret \\ 2)Department of Obstetrics and Gynecology, Dr. Moewardi Hospital, Surakarta \\ 3)Faculty of Medicine, Universitas Sebelas Maret
}

\begin{abstract}
Background: Postpartum haemorrhage is the primary cause of maternal mortality worldwide. However, studies in Indonesia examining factors associated with postpartum haemorrhage are sparse. The purpose of this study was to examine factors associated with postpartum haemorrhage.

Subjects and Method: This was an analytic observational study with a case-control design. The study was conducted at Dr. Moewardi hospital, Surakarta, Central Java, from May 2017 to May 2018. A total sample of 200 postpartum mothers was selected by fixed disease sampling. The dependent variable was postpartum haemorrhage. The independent variables were age, parity, birth space, anaemia, antenatal care, obstetrics history, education, and self-efficacy. The data were collected by questionnaire and analyzed by path analysis on Stata 13 .

Results:Postpartum haemorrhagewas positively and diretlyassociated with poor obstetric history $(b=0.87 ; 95 \% C I=-0.03$ to $1.79 ; p=0.059)$, older age $(b=1.86 ; 95 \% C I=0.81$ to $2.92 ; p=$ o.o01), multiparity $(b=1.62 ; 95 \% \mathrm{CI}=0.08$ to $3.15 ; \mathrm{p}=0.038)$, anemia $(b=1.74 ; 95 \% \mathrm{CI}=0.83$ to 2.66 ; $\mathrm{p}<0.001)$, and narrow birth space $(\mathrm{b}=-2.51 ; 95 \% \mathrm{CI}=-3.56$ to $-1.47 ; \mathrm{p}<0.001)$. Postpartum haemorrhage was indirectly associated with antenatal care, education, and self-efficacy.

Conclusion: Postpartum haemorrhageis positively associated with poor obstetric history, older age, multiparity, anemia, and narrow birth space. Postpartum haemorrhage is indirectly associated with antenatal care, education, and self-efficacy
\end{abstract}

Keywords: postpartum haemorrhage, determinant, path analysis

\section{Correspondence:}

Rizqa Kartika Dewi. Masters Program in Public Health, Universitas Sebelas Maret, Jl. Ir. Sutami 36 A, Surakarta 57126, Central Java. Email: rizqakartika@gmail.com.

\section{BACKGROUND}

Maternal mortality rate (MMR) is one of the indicators to assess the degree of public health. Based on the 2015 AKI Population Survey (SUPAS) in Indonesia, there were 305 per 100,000 live births. This figure is still quite high when compared to the target set by SDGs (Sustainable Development Goals) by 2030, meaning that AKI can reach below 70 per 100,000 births life. Based on data from the Central Java Provincial Health Office in 2016, the maternal mortality rate was 109.65 per 100,000 live births. Postpartum haemorrhage is one of the main causes of maternal death. Bleeding often occurs due to complications during pregnancy and childbirth (MoH RI, 2016, Central Java Health Office, 2016; Ministry of Health RI, 2015).

Based on data from the Ministry of Health of the Republic of Indonesia, in 2014, the incidence of maternal bleeding in Indonesia amounted to $30.3 \%$ in 2013, while based on Central Java Provincial Health Office in 2016, bleeding incidence amounted to $33.22 \%$. In Surakarta, in 2015, there were 5 cases of maternal deaths, which occurred in postpartum and caused 
by bleeding and eclampsia (Ministry of Health, 2014; Central Java Health Office, 2016; Health Office Surakarta, 2016).

There are several factors that influence the occurrence of postpartum hemorrhage, such as too young age under the age of 20 , this is because the female reproductive function is not fully perfect for pregnancy and childbirth, while at the age of too old at over 35 years, female reproductive function begin weakening that can increase the risks at the time of birth which is postpartum hemorrhage. Education and distance of pregnancy can also affect the occurrence of postpartum hemorrhage because low-educated mothers are less informed, whereas too close and farreaching pregnancies can lead to maternal complications during delivery (Cavazosrehg et al., 2015).

Parity and anemia can also affect the occurrence of postpartum hemorrhage because women who have high parity have decreased their reproductive function. Meanwhile women suffering from anemia during pregnancy cause uterine muscle to become weak that can cause uterine atony (Oberg et al., 2014).

Based on a study conducted by Nyfløt et al (2017), it was found that there was an influence of obstetric history on the incidence of postpartum hemorrhage, since mothers with a history of postpartum hemorrhage in previous delivery were more at risk than mothers without a history of postpartum hemorrhage. Inadequate antenatal care (ANC) visits in pregnant women may also increase the incidence of postpartum hemorrhage, because with regular ANC, it can detect premature likelihood of occurrence of disease that arises during pregnancy, so that it can be handled immediately if there are complications. Mothers who have low self-efficacy at the time of delivery indirectly may lead to complica- tions in the case of birth delivery, due to mothers with low efficacy (Afolabi et al, 2013; Fadel et al., 2016; WHO, 2012).

The purpose of this study was to analyze the relationship of age, parity, gestational distance, anemia, antenatal care, obstetric history, education, self efficacy.

\section{SUBJECTS AND METHOD}

\section{Study design}

The was an analytic observational study with a case control design. The study was conducted in Surakarta.

\section{Population and samples}

The target population in this study was all mothers giving birth, while the source population in this study was the mothers who gave birth at Dr. Moewardi hospital and Surakarta, Central Java, in May 2017 to May 2018. A sample of 200 postpartum mothers was selected by fixed disease sampling, consisting of 50 postpartum mothers with hemorrhage and 150 postpartum mothers without hemorrhage.

\section{Study variables}

The dependent variable was postpartum hemorrhage. The independent variables included age, parity, gestational distance, anemia, antenatal care, obstetric history, education, self efficacy.

\section{Operational definition of variables}

Postpartum haemorrhage was defined as a loss of $500 \mathrm{ml}$ of blood from the placental implant site, which occurs after the baby is born. Age was defined as the age of the mother at the time of delivery.

Parity was defined as the number of children born to mothers either living or dying. Antenatal care was defined as the first pregnancy check up before delivery. Obstetric history was defined as a difficult complication during pregnancy, labor, childbirth, before. Birth spacing was defined as the distance between the current 
pregnancy and the previous pregnancy. Anemia was defined as a maternal condition with hemoglobin levels $<11 \mathrm{~g} / \mathrm{dL}$. Education was defined as a formal education level that includes the level of elementary, junior high, high school and college that will affect health behavior. Self-efficacy was defined as the conviction/ ability of within a person to face the birth delivery.

\section{Study Instruments}

The data collection technique was conducted using primary data and secondary data. The primary data were obtained using questionnaires containing the characteristics of study subjects. The secondary data were obtained from medical record and maternal and child monitoring book.

\section{Data Analyis}

The data analysis was done using path analysis with program stata 13 to know the relation of the independent variable and the dependent variable and to know the relation on those variables.

\section{Research Ethics}

The research ethics included informed consent, anonymity, confidentiality and ethical clearance. The ethical clearance in this study was conducted at Dr. Moewardi hospital Surakarta and was declared as worthy of ethics based on the decision letter number: 387 / IV / HREC / 2018.

$\frac{\text { RESULTS }}{\text { 1. Univariate Analysis }}$

Table 1 shows that the study subjects aged 20-35 years were 162 mothers (81\%), and those aged $<20,>35$ years were 38 mothers (19\%). Mothers who have 2-4 children were 182 mothers (91\%), and who have >4 children were 18 mothers (9\%). Mothers with distance of pregnant <2 years were 33 mothers (15.5\%), and who have a gestational distance $\geq 2$ years were 167 mothers (83.5\%). Mothers with hemoglobin level of $11 \mathrm{~g} / \mathrm{dL}$ were 123 mothers (61.5\%), and who had hemoglobin $<11 \mathrm{~g} / \mathrm{dL}$ were 77 mothers (38.5\%). Mothers who visited antenatal care $<4$ times were 28 mothers (14\%), and those who had antenatal care visits $>4$ times were 172 mothers (86\%). Mothers with no previous obstetric history in pregnancy and labor were 125 mothers (62.5\%), and women who had a previous history of obstetrics in pregnancy and delivery were 75 (37.5\%). Mothers with low education were 57 mothers (28.5\%), and mothers who had higher education were 143 mothers (71.5\%). Subjects with low selfefficacy were 83 mothers (41.5\%), and those with high self-efficacy were 83 mothers (58.5\%)

Table 1. The results of univariate analysis

\begin{tabular}{lcc}
\hline \multicolumn{1}{c}{ Variable } & n & (\%) \\
\hline Postpartum bleeding & & \\
No & 150 & 75.0 \\
Yes & 50 & 25.0 \\
Age & & \\
20-35 years old & 162 & 81.0 \\
<20, > 35 years old & 38 & 19.0 \\
Parity & & \\
2-4 years & 182 & 91.0 \\
> 4 years & 18 & 9.0 \\
Pregnancy distance & & \\
< 2 years & 33 & 15.5 \\
$\geq 2$ years & 167 & 83.5 \\
Anemia & & \\
$\geq 11$ g/dL & 123 & 61.5 \\
< 11 g/dL & 77 & 38.5 \\
Antenatal Care & & \\
< 4 times & 28 & 14.0 \\
> 4 times & 172 & 86.0 \\
Obstetric History & 125 & 62.5 \\
No & 75 & 37.5 \\
Yes & & \\
Education & 57 & 28.5 \\
Low & 143 & 71.5 \\
High & & \\
Self-Efficacy & 83 & 41.5 \\
Low & 117 & 58.5 \\
High & & \\
\hline
\end{tabular}


Journal of Maternal and Child Health (2018), 3(3): 207-215

https://doi.org/10.26911/thejmch.2018.03.03.05

\section{Bivariate Analysis}

Bivariate analysis was used to observe the association of independent variables (age, parity, gestational distance, anemia, antenatal care, obstetric history, education, self efficacy) with the dependent variable (incidence of postpartum hemorrhage). The result of bivariate analysis can be seen in Table 2.

Table 2. The results of bivariate analysis

\begin{tabular}{|c|c|c|c|c|c|c|c|c|c|}
\hline \multirow{2}{*}{ Variable } & \multicolumn{2}{|c|}{$\begin{array}{c}\text { No } \\
\text { bleeding }\end{array}$} & \multicolumn{2}{|c|}{ Bleeding } & \multicolumn{2}{|c|}{ Total } & \multirow{2}{*}{ OR } & \multirow{2}{*}{ 95\% CI } & \multirow[b]{2}{*}{$\mathbf{p}$} \\
\hline & $\begin{array}{c}n= \\
150\end{array}$ & $\%$ & $\begin{array}{l}\mathbf{n}= \\
50\end{array}$ & $\%$ & $\begin{array}{c}\mathbf{n}= \\
200\end{array}$ & $\%$ & & & \\
\hline Age & & & & & & & & 2.66 to & \\
\hline 20-35 years old & 133 & 82.1 & 29 & 17.9 & 162 & 100 & 5.66 & 12.05 & $<0.001$ \\
\hline$<20,>35$ years old & 17 & 44.7 & 21 & $55 \cdot 3$ & 38 & 100 & & & \\
\hline Parity & & & & & & & & 3.41 to & $<0.001$ \\
\hline 2-4 years & 145 & 79.7 & 37 & 20.3 & 182 & 100 & 10.12 & 30.39 & \\
\hline$>4$ years & 5 & 27.8 & 13 & 72.2 & 18 & 100 & & & \\
\hline Birth spacing & & & & & & & & 0.44 to & $<0.001$ \\
\hline$<2$ years & 11 & $33 \cdot 3$ & 22 & 66.7 & 33 & 100 & 0.10 & 0.231 & \\
\hline$\geq 2$ years & 139 & 83.2 & 28 & 16.8 & 167 & 100 & & & \\
\hline Anemia & & & & & & & & 4.281 to & $<0.001$ \\
\hline$\geq 11 \mathrm{~g} / \mathrm{dL}$ & 111 & 90.2 & 12 & 9.8 & 123 & 100 & 9.013 & 18.97 & \\
\hline$<11 \mathrm{~g} / \mathrm{dL}$ & 39 & 50.6 & 38 & 49.4 & 77 & 100 & & & \\
\hline Antenatal Care & & & & & & & & 0.20 to & $<0.001$ \\
\hline$<4$ times & 6 & 21.4 & 22 & 78.6 & 28 & 100 & 0.53 & 55.88 & \\
\hline$>4$ times & 144 & 83.7 & 28 & 16.3 & 172 & 100 & & & \\
\hline Obstetric & & & & & & & & 0.143 to & $<0.001$ \\
\hline History & 73 & 94.8 & 4 & 5.2 & 77 & 100 & 17.98 & 52.01 & \\
\hline No history & 67 & 50.4 & 66 & 49.6 & 133 & 100 & & & \\
\hline With history & & & & & & & & & \\
\hline Education & & & & & & & & 0.222 to & 0.015 \\
\hline Low & 36 & 63.2 & 21 & 36.8 & 57 & 100 & 0.44 & 0.857 & \\
\hline High & 114 & 79.0 & 29 & 20.3 & 143 & 100 & & & \\
\hline Self-Efficacy & & & & & & & & 0.019 to & \\
\hline Low & 39 & 47.0 & 44 & 3.9 & 83 & 100 & 0.48 & 0.121 & $<0.001$ \\
\hline High & 111 & 94.9 & 6 & 80.2 & 117 & 100 & & & \\
\hline
\end{tabular}

Table 2 shows the results of bivariat analysis on the determinants of postpartum bleeding. Table 2 shows that maternal age $<20$ or $>35$ years, parity $>4$, anemia, and poor obstetrics history increased the risk of postpartum bleeding, and it was statistically significant. Birth spacing $\geq 2$ years, ANC $>4$ times, high education, and strong self efficacy decreased the risk of postpartum bleeding.

\section{The Result of Path Anaysis}

Table 3 showed that there was a significant relatonship between obestric history, age, parity, anemia, and birth spacing on postpartum haemorrhage.

Postpartum haemorrhage was directly and positively affected by obestric history ( $\mathrm{b}=0.87 ; 95 \% \mathrm{CI}=-0.03$ to $1.79 ; \mathrm{p}=0.059)$, age $(\mathrm{b}=1.86 ; 95 \% \mathrm{CI}=0.81$ to $2.92 ; \mathrm{p}=$ o.001), parity ( $\mathrm{b}=1.62 ; 95 \% \mathrm{CI}=0.08$ to $3.15 ; \mathrm{p}=0.038)$, anemia $(\mathrm{b}=1.74 ; 95 \% \mathrm{CI}=$ 0.83 to 2.66 ; $\mathrm{p}<0.001$ ), and birth spacing $(\mathrm{b}=-2.51 ; 95 \% \mathrm{CI}=-3.56$ to $-1.47 ; \mathrm{p}<0.001)$.

Postpartum haemorrhage was indirectly affected by birth spacing, education, parity, self efficacy, and antenatal care. 


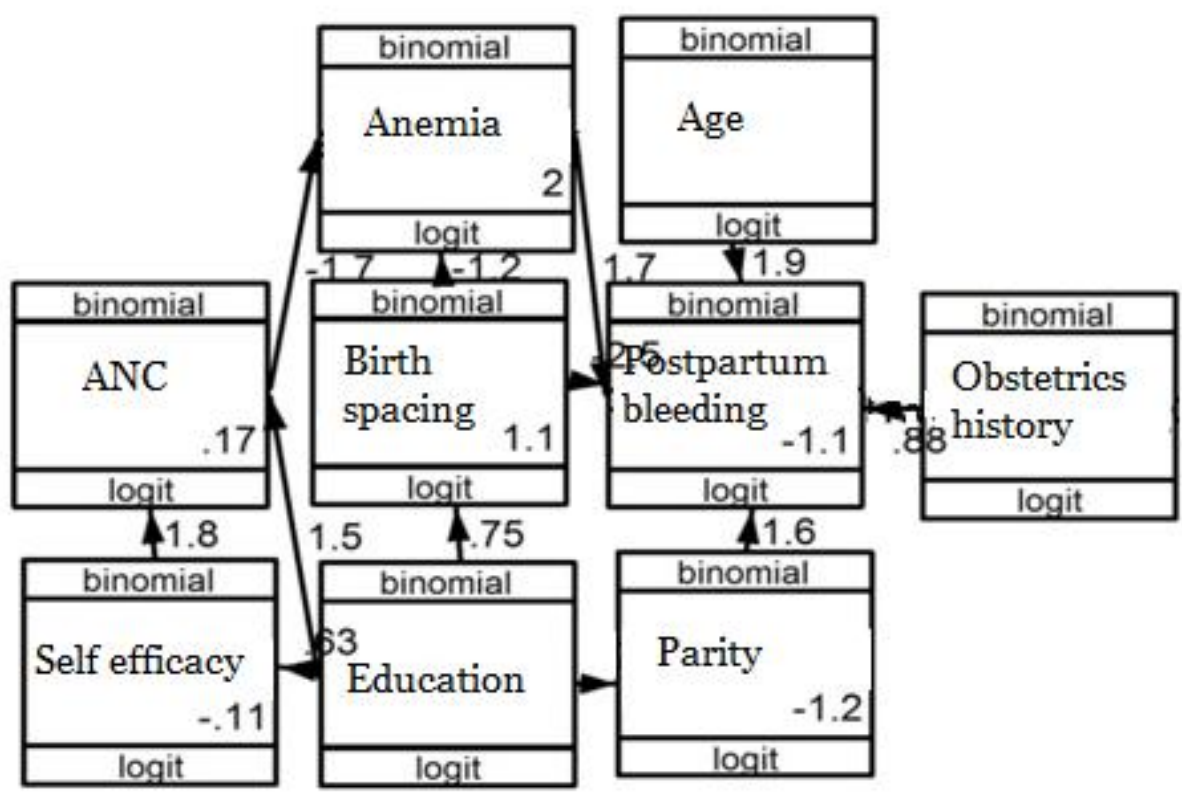

Figure 1. Path analysis model with estimation

Table 3.The Result of Path Anaysis

\begin{tabular}{lllcccc}
\hline \multirow{2}{*}{ DependentVariable } & & IndependentVariable & b & $\begin{array}{c}\text { Lower } \\
\text { Limit }\end{array}$ & $\begin{array}{c}\text { Upper } \\
\text { Limit }\end{array}$ & p \\
\hline Direct Effect & & & & & & \\
Postpartum Haemorrhage & $\leftarrow$ & Obestric history & 0.87 & -0.33 & 1.79 & 0.059 \\
Postpartum Haemorrhage & $\leftarrow$ & Age & 1.86 & 0.81 & 2.92 & 0.001 \\
Postpartum Haemorrhage & $\leftarrow$ & Parity & 1.62 & 0.08 & 3.15 & 0.038 \\
Postpartum Haemorrhage & $\leftarrow$ & Anemia & 0.74 & 0.83 & 2.66 & $<0.001$ \\
Postpartum Haemorrhage & $\leftarrow$ & Birth spacing & -2.51 & -3.56 & -1.47 & $<0.001$ \\
Indirect Effect & & & & & & \\
Anemia & $\leftarrow$ & Birth spacing & -1.21 & -2.04 & -0.38 & 0.004 \\
Anemia & $\leftarrow$ & Antenatal Care & -1.66 & -2.59 & -0.72 & 0.001 \\
Parity & $\leftarrow$ & Education & -2.09 & -3.18 & -1.01 & $<0.001$ \\
Birth spacing & $\leftarrow$ & Education & 0.75 & 0.01 & 1.52 & 0.056 \\
Antenatal Care & $\leftarrow$ & Education & 1.50 & 0.63 & 2.38 & 0.001 \\
Antenatal Care & $\leftarrow$ & Self-efficacy & 1.79 & 0.81 & 2.77 & $<0.001$ \\
Self-efficacy & $\leftarrow$ Education & 20.63 & 0.14 & 1.25 & 0.045 \\
\hline
\end{tabular}

\section{DISCUSSIONS}

\section{The relationship between obstetric history and postpartum bleeding}

The result of this study showed that obstestric history was associated with the incidence of postpartum haemorrhage and it was statistically significant.

The result of this study is consistent with a study by Nyfløt et al. (2017), which stated that there was a relatonship between obestric history and the incidence of postpartum haemorrhage. The history of com- plications in pregnancy and labor may potentially lead to complications in subsequent pregnancies and labor. If history of past labor has complications, health personnel should be watchful to the incidence of complications in pregnancy and labor.

\section{The relationship between age and} postpartum haemorrhage

The result of this study showed that maternal age was associated with the incidence of postpartum haemorrhage and it was statistically significant. 
The result of this study is consistent with a study by Sheldon et al. (2014), which stated that there was a relatonship between maternal age and the incidence of postpartum haemorrhage. The characteristic of pregnant women based on the age was very influential in attention and preparation in the process of birth delivery. Healthy reproductive age that was safe to experience pregnancy and labor was at the age of 2035 years old (Kerr et al., 2016).

\section{The relationship between parity and postpartum haemorrhage}

The result of this study showed that the number of children was associated with postpartum haemorrhage and it was statistically significant.

The result of this study is consistent with a study by Marshall et al. (2017), which stated that there was a relatonship between parity and the incidence of postpartum haemorrhage. Women with high parity have a greater risk of postpartum hemorrhage, because mothers who often give birth would experience a decrease in reproductive or uterine function that can lead to weak contractions during laborso that it can lead to uterine atony.

\section{The relationship between anemia and postpartum haemorrhage}

The result of analysis showed that there was an effect between anemia and postpartum haemorrhage and it was statistically significant.

The result of this study was in line with a study by Uygungül et al. (2014), which stated that there was a relatonship between anemia and the incidence of postpartum haemorrhage. Mothers who have hemoglobin level of $<11$ in pregnancy may experience complications, due to reduced blood levels in the body, resulting in a lack of oxygen transferred to the cells of the body or brain and uterus.A decreased amount of oxygen caused the uterine muscles to not contract adequately so that it caused uterine atony.

\section{The relationship between birth spacing and postpartum haemor- rhage}

The result of analysis showed that there was an effect between birthspacing and postpartum haemorrhage. Birth spacing $>2$ years decreased the risk of postpartum hemorrhage.

The result of this study was in line with a study by Fan et al., (2017) and Briley et al., (2014) which stated that there was a relatonship between birth spacing and the incidence of postpartum haemorrhage. The optimal birth spacing was 36 months. If the gap was too close, it can cause complications during pregnancy and labor. Short birth spacing would directly affect the maternal and infant health.

\section{The relationship between ANC and postpartum haemorrhage}

The result of analysis showed that there was an effect between ANC and postpartum haemorrhage through anemia. Mother with ANC $>4$ times decreased the risk of anemia during pregnancy.

The result of this study was in line with a study done by Obossou et al., (2015), which stated that there was an indirect relatonship between antenatal care and the incidence of postpartum haemorrhage. Mothers who did check up during pregnancy for $>4$ times would reduce the incidence of postpartum haemorrhage, because mothers who often check the pregnancy would easily detect the complications during pregnancy.

7. The relationship between education and postpartum haemorrhage The result of analysis showed that education through parity, birth spacing, antenatal care, and self-efficacy affected the incidence of postpartum haemorrhage. 
The result of this study is consistent with a study by Hanson et al., (2015), which stated that there was a relatonship between education and parity. This study is also consistent with a study by Al-Ateeq et al. (2015), which stated that there was a relatonship between education and antenatal care visit. Kuo et al. (2014) stated that there was a relatonship between education and self-efficacy. Maternal education has an indirect relationship with the incidence of postpartum haemorrhage, the higher the maternal education, the lower the incidence of postpartum haemorrhage.

\section{The relationship between self-effi- cacy and postpartum haemorrhage}

The result of analysis showed that there was a relationship between self-efficacy and the incidence of postpartum haemorrhage through antenatal care.

This was in line with a study by Briley et al. (2014), which stated that there was a relatonship between self-efficacy and postpartum haemorrhage. Mothers who have high self-efficacy during pregnancy would have more frequent pregnancy check up, therefore, the mother knew the development of mother and baby, so that optimal health could be achieved and the mother knew about her pregnancy.

\footnotetext{
REFERENCES

Obossou AAA, Salifou K, Hounkpatin B, Sidi I, Hounkponou A, et al. (2015) Risk Factors for Immediate Postpartum Hemorrhages in the Maternity of the University Teaching Hospital of Parakou. GynecolObstet (Sunnyvale) 5:284. doi:10.4172/21610932.1000284

Afolabi AF,Adeyemi AS (2013). Grandmultiparity: Is it still an obstetric risk?. 411-415. doi: 10.4236/ojog.2013.34075 .
}

Al-Ateeq, Mohammed A, Al-Rusaiess AA (2015). Health education during antenatal care: the need for more. International Journal of Women's Health, 7: 239-242.

Briley A, Seed PT, Tydeman G, Ballard H, Waterstone M, SandallJ, Poston L, Tribe RM, Bewley S (2014). Reporting errors, incidence and risk factors for postpartum haemorrhage and progression to severe $\mathrm{PPH}$ : A prospective observational study, BJOG: An International Journal of Obstetrics and Gynaecology, 121(7): 876-888. doi: 10.1111/1471-0528.12588.

Cavazos-Rehg PA, Krauss MJ, Spitznagel EL, Bommarito K, Madden T, Olsen MA, Subramaniam H, Peipert JF, Bierut LJ (2015). Maternal age and risk of labor and delivery complications.Matern Child Health J. 19(6): 1202-11. doi: 10.1007/s10995-0141624-7.

Dinas Kesehatan Provinsi Jawa Tengah (2016). Profil Kesehatan Provinsi Jawa Tengah Tahun 2016 3511351(24): 47-83.

Dinas Kesehatan Kota Surakarta (2016). ProfilKesehatan Kota Surakarta 2016.

Fan D, Wu S, Liu L, Xia Q, Wang W, GuoX, Liu Z (2017). Prevalence of antepartum hemorrhage in women with placenta previa: a systematic review and meta-analysis. Sci. Rep. 7: 40320.doi: 10.1038/srep40320.

Fadel MG, Yoong W (2016).Severe IronDeficiency Anemia on Maternal and Neonatal Outcomes. Journal of Pregnancy and Child Health, 3(2): 10-12. doi: 10.4172/2376-127X.1000242.

Hanson C, Cox J, Mbaruku G, Manzi F, Gabrysch S, Schellenberg D, Tanner M, Ronsmans C, Schellenberg J (2015). Maternal mortality and distance to facility-based obstetric care 
in rural southern Tanzania: A secondary analysis of cross-sectional census data in 226 ooo households. The Lancet Global Health. 3(7): e387e395. doi: 10.1016/S2214-109X(15)00048-0.

Kemenkes RI (2015) Kesehatan dalam Kerangka Sustainable Development Goals (SDGs). Rakorpop KementerianKesehatan RI, (97), p. 24. Available at: http://www.pusat2.litbang.depkes.go.id/pusat2_v1/wpcontent/uploads/2015/12/SDGs-Ditjen-BGKIA.pdf.

(2016).ProfilKesehatan Indonesia, ProfilKesehatanProvinsi Bali. (2014).InfodatinPusat Data danInformasiKementerianKesehatan RI', Pusat Data danInformasiKementerianKesehatan RI: PenyebabKematianIbu. Available at: www.depkes.go.id/-resources/download/pusdatin/infodatin/infodatin-ibu.pdf.

Kerr R, Eckert LO, Winikoff B, Durocher J, Meher S, Fawcus S, Mundle S, et al. (2016). Postpartum haemorrhage: Case definition and guidelines for data collection, analysis, and presentation of immunization safety data', Vaccine, 34(49): 6102-6109. doi: 10.1016/j.vaccine.2016.03.039.

Kuo YC, Walker AE, Schroder KEE, Belland BR (2014). Interaction, Internet selfefficacy, and self-regulated learning as predictors of student satisfaction in online education courses. Elsevier BV, 20: 35-50. doi: 10.1016/j.iheduc.2013.10.001.

Lao TT, Sahota DS, Cheng YK, Law LW, Leung TY. (2014). Advanced maternal age and postpartum hemorrhage risk factoror red herring?.J Matern Fetal Neonatal Med. 27(3):243-6. doi: 10.3109/14767058.2013.807240.
Leveno KJ, Cunningham FG, Alexander JM, Bloom SL, Casey BM, Dashe JS, Sheffield JS, Yosh, NP.(2009). Obstetri Williams. Jakarta: EGC

Marshall AL, Durani U, Bartley A, Hagen CE, AshraniA, Rose C, Go RS, Pruthi RK (2017). The impact of postpartum hemorrhage on hospital length of stay and inpatient mortality: a National Inpatient Sample-based analysis. American Journal of Obstetrics and Gynecology. Elsevier Inc., 217(3): 344.e1-344.e6. doi: 10.1016/j.ajog.2017.05.004.

Masukume G, Khashan AS, Kenny LC, Baker PN, Nelson G (2015). Risk factors and birth outcomes of anaemia in early pregnancy in a nulliparous cohort. PLoS ONE, 1O(4), 115. https://doi.org/10.1371/journal.pone.0122729.

Maupin AN, Rutherford HJV, Landi N, Potenza MN, Mayes LC (2018). Investigating the association between parity and the maternal neural response to infant cues. Journal: Social Neuroscience.DOI: 10.1080/17470919.2017.1422276.

Mavrides E, Allard S, Chandraharan E, Collins P, Green L, Hunt BJ, Riris S, Thomson AJ (2016). Prevention and management of postpartum haemorrhage.Royal College of Obstetricints and Gynaecologists; BJOG.

Murti B (2016). Prinsip dan Metode Riset Epidemiologi. Surakarta: Progam Studi Ilmu Kesehatan Masyarakat, Progam Pascasarjana Universitas Sebelas Maret.

Muyunda B, Makasaa M, Jacobs C, Musonda P, Michelo C (2016). Higher Educational Attainment Associated with Optimal Antenatal Care Visits among Childbearing Women in Zambia. journal Frontiers in Public Health 
Nyfløt LT, Sandven I, Pedersen BS, Pettersen S, Al-Zirqi I, Rosenberg M, Jacobsen AF, VangenS (2017).Risk factors for severe postpartum hemorrhage: A case-control study.BMC Pregnancy and Childbirth. BMC Pregnancy and Childbirth, 17(1): 1-9. doi: 10.1186/s12884-016-1217-0.

Nakagawa K, Yamada T, Cho K. Akaishi R, Kohogo Y, Hanatani K, Minakami H. (2016). Independent Risk Factors for Postpartum Haemorrhage. Journal Critical Care Obstetrics and Gynecology.

Oberg AS, Hernandez-Diaz S, Palmsten K, Almqvist C, Bateman BT (2014). Patterns of recurrence of postpartum hemorrhage in a large populationbased cohort. American Journal of Obstetrics and Gynecology. Elsevier
Inc, 210(3): 229.e1-229.e8. doi: 10.1016/j.ajog.2013.10.872.

Sheldon WR, Blum J, Vogel JP, Souza JP, Gülmezoglu AM, WinikoffB, WHO Multicountry Survey on Maternal and Newborn Health Research Network. (2014). Postpartum haemorrhage management, risks, and maternal outcomes: findings from the World Health Organization Multicountry Survey on Maternal and Newborn Health. BJOG: an international journal of obstetrics and gynaecology, 121(1): 5-13. doi: 10.1111/1471-0528.12636.

Uygungül E, Ayrik C, Narci H, Erdoğan S, Toker I, Demir F, Karaaslan U (2014) Determining Risk Factors of Bleeding in Patients on Warfarin Treatment. AdvHematol. 369084. doi: 10.1155/2014/369084 